\title{
Comparison of the physiological responses of an oil-pumpkin cultivar andhybrid under different nitrogen supply conditions
}

\author{
${ }^{1}$ Soma Gáspár Gáspár - ${ }^{2}$ László Zsombik $-{ }^{1}$ Szilvia Veres \\ ${ }^{1}$ DE, MÉK, Institute of Plant Sciences, Department of Agricultural Botany, Crop Physiology and Biotechnology, Debrecen, Hungary \\ ${ }^{2}$ Research Institute of Nyíregyháza, Institutes for Agricultural Research and Educational Farm, University of Debrecen, Westsik Vilmos str. \\ 4-6, Nyíregyháza, Hungary \\ gasparsomagaspar@gmail.com
}

\section{SUMMARY}

Cucurbita pepo var. styriaca is known as a medicinal crop among other cucurbits. The benefits of cucurbits fruits are very important in terms of human health, purification of blood, removal of constipation, digestion and supplying energy. The mutant styrian oil-pumpkin (Cucurbita pepo L. convar. Pepo var. styriaca Greb.) exposes a complete lack of lignification of the seed testa. For this reason, this kind of naked pumpkin seed is more consumable as snack than other seeds. The vegetative growth of plants is crucial for fruit production. Nitrogen is the most imperative element for the proper vegetative growth and development of plants which significantly increases and enhances yield and its quality by playing a vital role in the biochemical and physiological functions of plants.

Field studies were conducted to study the effect of nitrogen nutrition on certain physiological parameters and their differences between the styrian oil pumpkin hybrid and cultivar (Gleisdorfi Classic cultivar and GL Rustical hybrid). The small block experiment was carried out based on a factorial experiment with a completely randomised block design and four replications in the Research Institute of Nyiregyháza during the summer period of 2017 and 2018. Three different concentrations of nitrogen fertiliser was applied at sowing. Photosynthetic pigments (chlorophyll-a, -b and carotenoids) were analysed as one of the basic factor of efficient photosynthesis. The yields of two genotypes were also measured in all treatments as seed-weight. The contents of photosynthetic pigments were higher in the oil-pumpkin hybrid, mainly the carotenoids in 2018. The vegetation period of 2018 was drier than in 2017, the hybrid oil-pupmkin was more efficient in stress tolerance than the cultivar with higher carotenoids pool. The obtained yield was more pronounced in the oil-pumpkin hybrid than the cultivar in all examined years. The hybrid GL Rustical was more sensitive to nitrogen treatment than the cultivar Gleisdorfi Classic.

Keywords: chlorophylls, carotenoids, oil-pumpkin, nitrogen, yield

\section{INTRODUCTION}

The approximate time of spreading of a naked seeded, also called thin-coated or hull-less mutant of Cucurbita pepo subsp. pepo in the southwestern part of the then Austro-Hungarian Monarchy appears to be dated between 1870 and 1880 (Teppner, 2004). In the USA Curtis (1948) first recognized the potential value of naked seeded pumpkin for producing a high quality vegetable oil and for use as a snack seed, and initiated the first breeding program at the University of Connecticut. The mutant styrian oil-pumpkin (Cucurbita pepo L. convar. Pepo var. styriaca Greb.) exposea a complete lack of lignification of the seed testa, thus this kind of naked pumpkin seeds are more consumable as a snack, than other seeds.

The crucial nutritionally relevant components of pumpkin seeds are protein and oil (Howitt and Pogson, 2006; Robinson, 1981). The main fatty acids of pumpkin seeds are palmitic acid, stearic acid, oleic acid, and linoleic acid. Depending on climatic conditions, the fatty acid composition is subject to variation. Abiotic factors, like temperature can influence oil composition. When the temperature is lower during the last weeks of seed filling, there will be a shift from oleic to linoleic acid (Murkovic et al., 1999). Because of significant amount of tocotrienols Cucurbita pepo var. styriaca is known as a medicinal crop among other cucurbits (Fruhwirth and Hermetter, 2007). The benefits of cucurbits fruits are very important in terms of human health, purification of blood, removal of constipation, good for digestion and supplying energy (Medjakovic et al., 2016). The soil parameters are also main factors in terms of seedless oil-pumpkin yield (Baxter et al., 2012), like soil pH (6.3 \pm 0.3 ) (Napier, 2009). The vegetative growth of plants is crucial for fruit production.

Nitrogen $(\mathrm{N})$ is most imperative element for proper vegetative growth and development of plants which significantly increases the yield and its quality by playing a vital role in biochemical and physiological functions of plant. Nitrogen is an important component of many important structural, genetic and metabolic compounds in plant cells, but our knowledge has several gaps (Krapp, 2015). It is a major component of chlorophylls and proteins taking part of photosynthtetic process and structure (McDonald et al., 1996). The increased crop productivity has been associated with a 20 -fold increase in the global use of nitrogen fertilizer during the 50 years (Glass, 2003), and this is expected to increase by 3 -fold by the year 2050 (Good et al., 2004). In terms of sustainable plant production need to achieve higher and higher amount of quality food by using less stock and energy under actual environmental conditions. Nevertheless, the inadequate supply of nitrogen has a strong and rapid effect on plant production (Naderi et al., 2015; Nagy, 2012; Pepó, 2007; Tóth, 2009). In the last decades several publications focus on yield and quality parameters of styrian oil pumpkin as affected by fertilizer treatments 
and genotypes (Habibi et al., 2014; Seymen et al., 2016; Gáspár et al., 2018a, 2018b).

The goal of this research is studying the influence of different amount of nitrogen supply on physiological parameters and their differences in hybrid a cultivar of oil-pumpkin.

\section{MATERIALS AND METHODS}

Field experiments were conducted to study the effect of nitrogen nutrition in different amount on photosynthetic pigment content and yield of seeds in styrian oil pumpkin (Gleisdorfi Classic cultivar and GL Rustical hybrid). Small block experiments were carried out based on factorial experiment with randomized completely blocks design by four replications in Research Institute of Nyíregyháza in 2017 and 2018. The NPK fertilizer concentration was 8:24:24 Nitrogen fertilizer was applied at sowing in three different concentrations ( $\mathrm{noN}=$ no additional $\mathrm{N}, \mathrm{N}=300$ $\mathrm{kg} \mathrm{ha}^{-1}$ (optimal, based on Aroiee and Omidbaigi 2004), $\left.1 / 2 \mathrm{~N}=150 \mathrm{~kg} \mathrm{ha}^{-1}, 2 \mathrm{~N}=600 \mathrm{~kg} \mathrm{ha}^{-1}\right)$. The main characteristics of experimental soil were described by Makádi, 2010.

The enviromental factors, like temperature and precipitation influences the physiological process of crops and the yield as well (Nagy, 2012; Pepó, 2009; Tardieu, 2013; Vári, 2014). The vegetation period of our examination was different, the average monthly temperature (Table 1) was higher in 2018 with at least $1^{\circ} \mathrm{C}$ except for May.

The value of monthly average temperature $\left({ }^{\circ} \mathrm{C}\right)$ in the vegetation period of 2017 and 2018

\begin{tabular}{cccccc}
\hline & April & May & June & July & August \\
\hline 2017 & $17^{\circ} \mathrm{C}$ & $21.2^{\circ} \mathrm{C}$ & $21.3^{\circ} \mathrm{C}$ & $22.3^{\circ} \mathrm{C}$ & $16.3^{\circ} \mathrm{C}$ \\
2018 & $19.6^{\circ} \mathrm{C}$ & $21.5^{\circ} \mathrm{C}$ & $22.5^{\circ} \mathrm{C}$ & $23.3^{\circ} \mathrm{C}$ & $17.6^{\circ} \mathrm{C}$ \\
\hline
\end{tabular}

Table 2

The value of monthly precipitation $(\mathrm{mm})$ in the vegetation period of 2017 and 2018

\begin{tabular}{cccccc}
\hline & April & May & June & July & August \\
\hline 2017 & $52.9 \mathrm{~mm}$ & $67 \mathrm{~mm}$ & $75 \mathrm{~mm}$ & $25.3 \mathrm{~mm}$ & $52.5 \mathrm{~mm}$ \\
2018 & $68.5 \mathrm{~mm}$ & $46.6 \mathrm{~mm}$ & $19.5 \mathrm{~mm}$ & $19.1 \mathrm{~mm}$ & $16.5 \mathrm{~mm}$ \\
\hline
\end{tabular}

The monthly precipitation was higher in April at 2018, than in 2017, but from May to August was lower rainfall in 2018 than in 2017 with approximately 100 $\mathrm{mm}$. Rainfall and temperature data shows, that oilpumpkin plant faced to water deficiency stress is 2018 .
The samples collections for photosynthetic pigment analysis were on the $1^{\text {st }}$ week of August in 2017 and 2018. The photosynthetic pigments were extracted according to Moran and Porath (1980) and the contents were calculated by Wellburn (1994) formulas. The harvests were both of the years in the middle of September, the yield was represented as row weight of seeds of each parcels. Microsoft Excel 2010 and SigmaPlot 12.0 for Windows were used for calculating results and statistical analyses.

\section{RESULTS AND DISCUSSION}

Photosynthesis is one of the main processes in terms of dry matter production of plants. Behind the efficient photosynthesis photosynthetic pigments are standing. The qualitative and quantitative establishment of photosynthetic pigments is suitable in the plant stress researches: salt stress (Sayyad-Amin et al., 2016), heat stress (Chalanika De Silva and Asaeda, 2017), nitrogen stress (Jin et al., 2015), etc.. Nitrogen (N) deficiency induces changes in many physiological processes, like the amount of photosynthetic pigments (McDonald et al., 1996). The results of the chlorophyll-a content of the oil-pumpin genotypes in 2018 shows (Figure 1.), that the hybrid GL Rustical has higher amount of chlorophyll-a - 5-10\% more - than the cultivar Gleisdorfi Rustical. These results were also found in case of chlorophyll-b as well (data not shown). Several studies have revealed that the total chlorophyll of leaves increases as the $\mathrm{N}$ supply increases (Filela et al., 1995).

In our experiments, the half amounts of optimum nitrogen supply $(1 / 2 \mathrm{~N})$ almost reach the values, like in optimum nitrogen supply in both examined genotypes. The double amount of nitrogen $(2 \mathrm{~N})$ reduced the level of chlorophylls. Based on Dai et al. (2003) the increasing $\mathrm{N}$ concentrations in plants can be an effective method to adjust the properties of photosynthetic pigments, improve the photosystem II (PSII) potential activity and increase the net photosynthetic rate (Dai et al., 2003).

Carotenoids are composed of carotenes and xanthophylls, and represent another key group of photosynthetic pigments. They participate in harvesting light energy for photosynthesis (Zakar et al., 2016) and are also involved in the defense mechanism against oxidative stress (Bouvier et al., 2005). Under low nitrogen supply carotenoid content are reduced as we can see on Figure 2. The application of nitrogen increased the content of carotenoids in both genotypes, except for double nitrogen supply $(2 \mathrm{~N})$. The amount of carotenoid was higher in the hybrid GL Rustical, mainly in 2017, because the water deficiency enhanced the amount of these photosynthetic pigments. Higher amount of carotenoids may have a role in stress resistance of hybrid oil-pumpkin GL Rustical. 
Figure 1: Values of the chlorophyll-a content ( $\left.\mathrm{mg} \mathrm{g}^{-1}\right)$ of two oil-pumpkin genotypes (Gleisdorfi Classic and GL Rustical) under different nitrogen supply (noN, 1/2N, N, 2N see in Materal and Methods) in 2017 and 2018, $n=4, \pm$ s.e. ***p $<0.001$ compare to noN
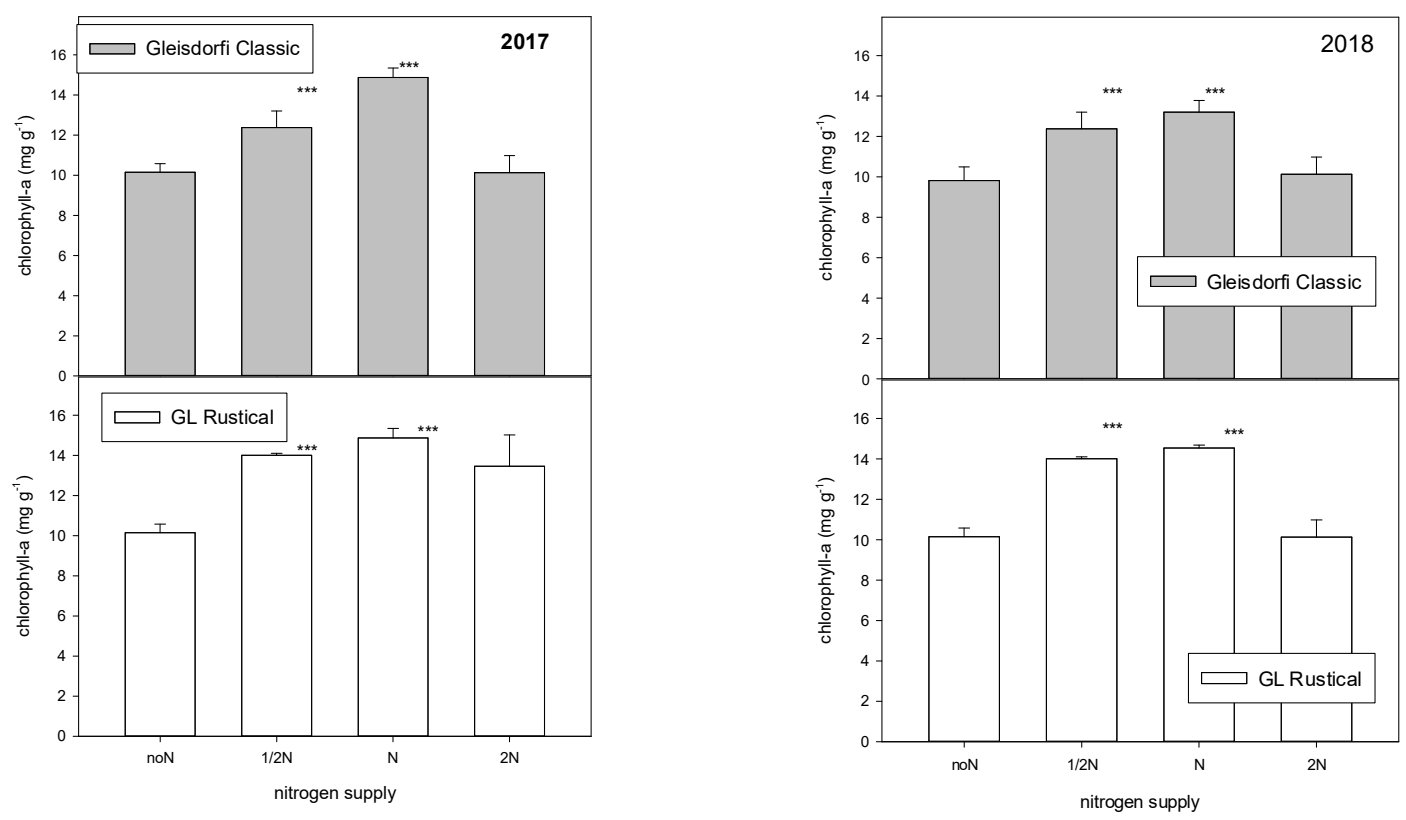

Figure 2: Values of the contents of carotenoids ( $\left.\mathrm{mg} \mathrm{g}^{-1}\right)$ in the two oil-pumpkin genotypes (Gleisdorfi Classic and GL Rustical) under different nitrogen supply (noN, $1 / 2 \mathrm{~N}, \mathrm{~N}, \mathbf{2 N}$ see in Materal and Methods) in $2018, n=4, \pm$ s.e. $* * * p<0.001, * * p<0.01$ compare to noN

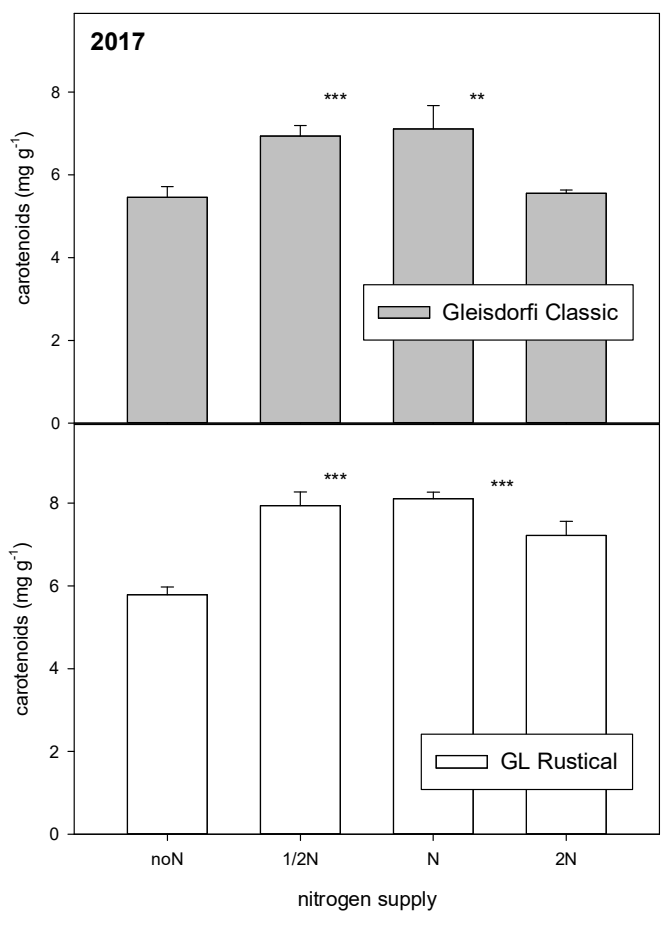

The yields of the examined two vegetation period are represented in Figure 3. The yield was higher in hybrid GL Rustical in both of the years, mainly in case of optimum nitrogen supply. No significant differences

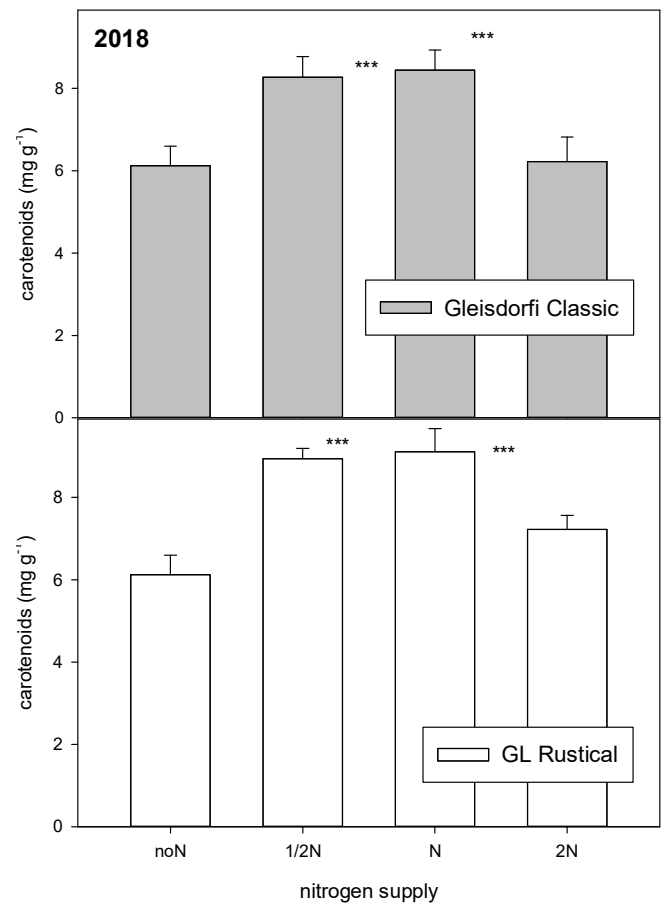

were observed in cultivar Gleisdorfi classic by the effect of different nitrogen supply. In 2017 and 2018 the optimum nitrogen supply resulted in significantly higher yield in hybrid GL Rustical. In the drier 
vegetation period of 2018 the lower amount of rainfall caused enhanced effect of half amount of applied nitrogen, than in 2017 , when the weather was wetter. The double amount of applied nitrogen increased the yield in 2017 and 2018, compare to the noN supply, but no means any additional increase compare to the optimum nitrogen supply (N).

Figure 3: Values of the yields (seed weight $\mathrm{kg} \mathrm{parcel}^{-1}$ ) in the two oil-pumpkin genotypes (Gleisdorfi Classic and GL Rustical) under different nitrogen supply (noN, 1/2N, N, 2N see in Materal and Methods) in 2017 and 2018, $n=4, \pm$ s.e. ***p<0.001 compare to noN

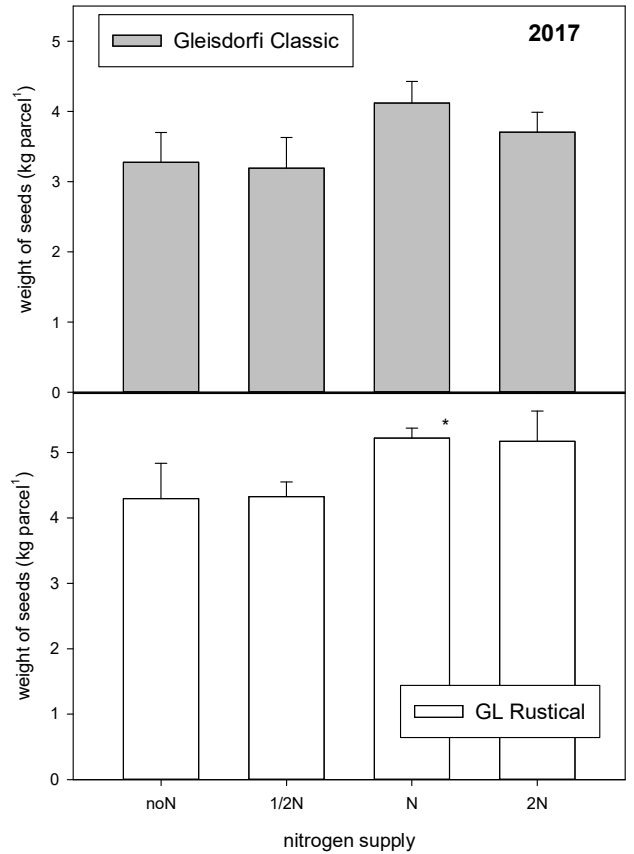

\section{CONCLUSION}

The applied nitrogen increased the amount of photosynthetic pigments, chlorophyll-a, $-\mathrm{b}$ and carotenoids, but the double amount of nitrogen $(2 \mathrm{~N})$ did not result in a higher amount of these components. The hybrid GL Rustical had a higher amount of photosynthetic pigments than the cultivar Gleisdorfi Classic, mainly in the case of carotenoids in the drier year of 2018. The higher carotenoid content may have a role in better stress tolerance and the higher yield of GL Rustical. Moreover, GL Rustical was more sensitive to nitrogen supply, half of the optimum amount enhanced the content of photosynthetic pigments.

Based on our results of two examined years and in terms of our measured parameters - chlorophyll-a, -b, carotenoids and yield - the double amount of optimum nitrogen supply $(2 \mathrm{~N})$ means excessive nitrogen for

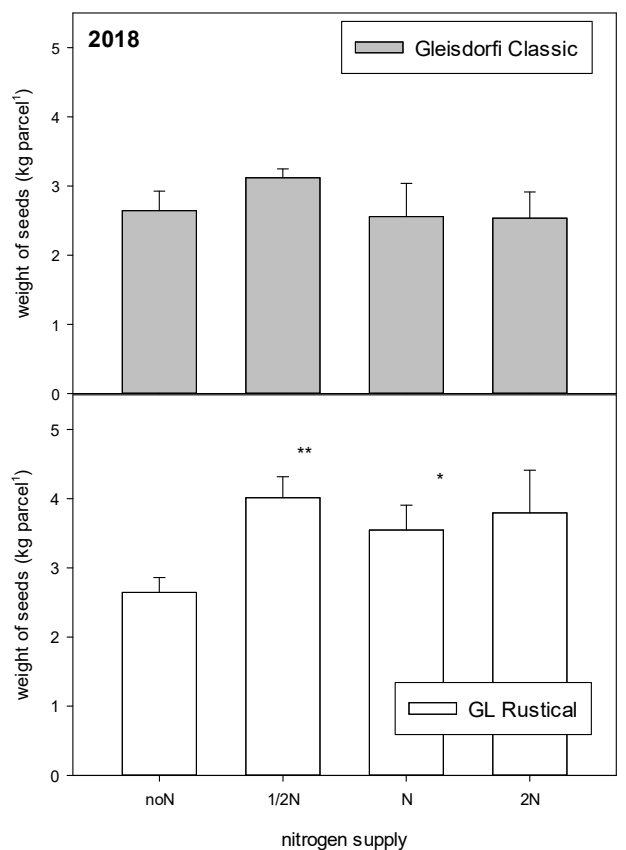

genotypes, and will not improve the yield of oilpumkin. Compared to the control (noN), the applied half and optimum amount of nitrogen increased the yield in both genotypes, but was more effective in the hybrid GL Rustical, than the cultivar Gleisdorfi Classic. Although, as we can see the weather conditions had strong influence on the efficiency of applied nitrogen fertilizer. The $1 / 2 \mathrm{~N}$ improving effect was higher in the drier 2018, but the average amount of yield was lower in both genotypes in this year.

\section{ACKNOWLEDGEMENTS}

The publication supported by the EFOP-3.6.3VEKOP-16-2017-00008 and "Establishing a scaleindependent complex precision consultancy system" (GINOP-2.2.1-15-2016-00001) projects.

\section{REFERENCES}

Aroiee, H.-Omidbaigi, R. (2004): Effects of nitrogen fertilizer on productivity of medicinal pumpkin. Acta Hort., 629.54: 415419.
Bardaa, S. B.-Halima, N.-Aloui, F. B.-Mansour, R.-Jabeur, H.Bouaziz, M. (2016): Oil from pumpkin (Cucurbita pepo L.) seeds: evaluation of its functional properties on wound healing in rats. Lipids Health Dis., 15: 1-12. 
Baxter, G. G.-Murphy, K.-Paech, A. (2012): The Potential to Produce Pumpkin Seed for Processing in North East Victoria. RIRDC Project No. PRJ-005518, publication No. 11/145. p. 56.

Bouvier, F.-Isner, J. C.-Dogbo, O.-Camara, B. (2005): Oxidative tailoring of carotenoids: A prospect towards novel functions in plants. Trends Plant Sci., 10: 187-194.

Chalanika De Silva, C. H.-Asaeda, T. (2017): Effects of heat stress on growth, photosynthetic pigments, oxidative damage and competitive capacity of three submerged macrophytes. Journal of Plant Interaction, 12.1: 228-236.

Curtis, L. C. (1948): The use of naked seed in Cucurbita pepo as a source of high quality liquid fat, as a high analysis protein, as a new confection, and as a sandwich spread. Proc. Am. Soc. Hort. Sci. 52, 403-406.

Dai, T. B.-Cao, W. X.-Sun, C. F.-Jiang, D.-Jing, Q. (2003): Effect of enhanced ammonium nutrition on photosynthesis and nitrate reductase and glutamine synthetase activities of winter wheat. Chin. J. Appl. Eco., 14: 1529-1532.

Filela I.-Serrano, L.-Serra, J.-Penuelas, J. (1995): Evaluating wheat nitrogen status with canopy reflectance indices and discriminant analysis. Crop Science, 35: 1400-1405.

Fruhwirth, G.-Hermetter, A. (2007): Seeds and oil of the Styrian oil pumpkin: Components and biological activities. European Journal of Lipid Science and Technology, 109.: 1128-1140.

Gáspár, S. G.-Zsombik, L.-Veres, Sz. (2018a): Eltérő mennyiségü nitrogén ellátás hatása héjnélküli olajtök néhány fiziológiai paraméterére. (in Hungarian). Növénytermelés, 67: 23-34.

Gáspár, S. G.-Zsombik, L.-Veres, Sz. (2018b): Influence of nitrogen supply on the vegetative development of different styrian oil pumpkin genotypes. Abstract Volume of 60th Georgikon Scientific Conference. LX. Georgikon Napok, 2018. október 45. Keszthely, poster 91., p. 59.

Glass, A. D. M. (2003): Nitrogen use efficiency of crop plants, physiological constraints upon nitrogen absorption. Critical Review Plant Sciences, 22: 453-470.

Good, A. G.-Shrawat, A. K.-Muench, D. G. (2004): Can less yield more? Is reducing nutrient input into the environment compatible with maintaining crop production? Trends Plant Science, 9: 597605.

Habibi, A.-Heidari, G.-Sohrabi, Y.-Badakhshan, H. (2014): Effect of different fertilizer systems on yield and seed mineral elements of pumpkin. Iran Agricultural Research, 33.2: 83-94.

Howitt, C. A.-Pogson, B. J. (2006): Carotenoid accumulation and function in seeds and non-green tissues. Plant, Cell and Environment. 29: 435-445.

Jin, X.-Jang, G.-Tan, C.-Zhao, C. (2015): Effects on nitrogen stress on the photosynthetic $\mathrm{CO} 2$ assimilation, chlorophyll fluorescence and sugar-nitrogen ratio in corn. Scientific Reports, 5: 9311.

Krapp, A. (2015): Plant nitrogen assimilation and its regulation: a complex puzzle with missing pieces. Curr. Opin. Plant Biol., 25: $115-122$.

Makádi, M. (2010): Microbiological properties of sandy soils in the Nyírség region (Hungary), affected by organic and inorganic additives (in Hungarian). Ph.D. Thesis, University of Szent Istvan, Gödöllö, Hungary.

McDonald, A. J. S.-Davies, W. J. (1996): Keeping in touch: response of the whole plant to deficits in water and nitrogen supply. Advances in Botanical Research, 22: 229-300.

Medjakovic, S.-Hobiger, K.-Ardjomand-Woelkart, K.-Bucar, F.Jungbauer, A. (2016): Pumpkin seed extract: Cell growth inhibition of hyperplastic and cancer cells, independent of steroid hormone receptors. Fitoterapia, 110: 150-156.

Moran, R.-Porath, D. (1980): Chlorophyll determination in intact tissues using N,N-dimethylformamide. Plant Physiology. 65.3: 478-479.

Naderi, M. R.-Bannayan, M.-Goldani, M.-Alizadeh, A. (2015): Effect of nitrogen application on growth and yield of pumpkin. Journal of Plant Nutrition, 40.6: 890-907.

Napier, T. (2009): Pumpkin Production. Primefacts for Profitable, Adaptive and Sustainable Primary Industries: New South Wales Industry and Investment Primefact 1.964: 1-15.

Nagy, J. (2012): The effect of fertilization and precipitation on the yield of maize (Zea mays L.) in a long term experiment. Időjárás, 116.1: 39-53.

Pepó, P. (2007): The role of fertilization and genotype in sustainable winter wheat (Triticum aestivum L.) production. Cereal Research Communications, 35.2: 917-923.

Pepó, P. (2009): A kukorica (Zea mays L.) termése és növénydőlése száraz és csapadékos évjáratban csernozjom talajon. Növénytermelés, 58.3.: 53-66.

Robinson, R. G. (1981): Production of naked-seed pumpkin: a foodcrop for the family farm. Miscallaneous Report. University of Minesota, 156: 1-6.

Sayyad-Amin, P.-Jahansooz, M. R.-Borzouei, A.-Ajili, F. (2016): Changes in photosynthetic pigments and chlorophyll-a fluorescence attributes of sweet-forage and grain sorghum cultivars under salt stress. Journal of Biol. Phys., 42.4: 601-620.

Seymen, M.-Uslu, N.-Türkmen, Ö.-Juhaimi, F.-Özcan, M. M. (2016): Chemical compositions and mineral contents of some hull-less pumkin seed and oil. J. Am. Oil Chem. Soc., 93: 10951099.

Tardieu, F. (2013): Plant response to environmental conditions: assessing potential production, water demand, and negative effects of water deficit. Frontiers in Physiology, 4.17: PMC3574982

Teppner, H. (2004): Notes on Lagenaria and Cucurbita (Cucurbitaceae) - Review and new contribution. Phyton 44, 245-308

Tóth, Z.-Jolánkai, P.-Kismányoky, T. (2009): A mütrágyázás és az évjárat hatása a kukorica termésére monokultúra tartamkísérletben. V. Növénytermesztési Tudományos Nap. Növénytermesztés: Gazdálkodás - Klímaváltozás - Társadalom. Keszthely, november 19. Akadémiai Kiadó, Budapest. ISBN 978 $9630588041.241-244$.

Vári, E. (2014): Ökológiai és agrotechnikai tényezők hatásának összehasonlító vizsgálata eltérő fiziológiájú gabonanövényeknél. PhD értekezés, DE Hankóczy Jenő Növénytermesztési, Kertészeti és Élelmiszertudományok Doktori Iskola, p. 167.

Wellburn, A. R. (1994): The spectral determination of chlorophylls a and $\mathrm{b}$, as well as total carotenoids, using various solvents with spectrophotometers of different resolution. Journal of Plant Physiology. 144: 307-313.

Zakar, T.-Laczko-Dobos, H.-Toth, T. N.-Gombos, Z. (2016): Carotenoids assist in cyanobacterial photosystem II assembly and function. Front. Plant Sci., 7: 295. 
